\title{
Exposure to Short Day Photoperiod During the Dry Period Enhances Mammary Growth in Dairy Cows
}

\author{
E. H. Wall, ${ }^{1}$ T. L. Auchtung, ${ }^{2}$ G. E. Dahl, ${ }^{2}$ S. E. Ellis, ${ }^{3}$ and T. B. McFadden ${ }^{1}$ \\ ${ }^{1}$ Lactation and Mammary Gland Biology Group, Department of Animal Science, \\ University of Vermont, Burlington 05405 \\ ${ }^{2}$ Department of Animal Sciences, University of Illinois, Urbana 61801 \\ ${ }^{3}$ Animal and Veterinary Science Department, Clemson University, SC 29634
}

\begin{abstract}
Exposure to short day photoperiod (SD; 8 h light:16 $\mathrm{h}$ dark) during the dry period increased milk yield of cows in the subsequent lactation. We hypothesized that this effect is due to increased growth of mammary cells in response to enhanced prolactin signaling to influence the insulin-like growth factor (IGF) axis. Multiparous Holstein cows were dried off $60 \mathrm{~d}$ before parturition and assigned to long day photoperiod (LD; $16 \mathrm{~h}$ light:8 $\mathrm{h}$ dark) or SD during the dry period. Mammary biopsies were obtained at approximately $-40,-20,-10$ and +10 $\mathrm{d}$ relative to expected calving. Expression of IGF-I, IGFII, and IGF binding protein-5 mRNA was assessed by real time reverse transcription-polymerase chain reaction. In SD cows, incorporation of $\left[{ }^{3} \mathrm{H}\right]$-thymidine in vitro increased from $-40 \mathrm{~d}$ to $-20 \mathrm{~d}$ and was greater at $-20 \mathrm{~d}$ than in LD cows. A later increase in proliferation was observed at $-10 \mathrm{~d}$ in $\mathrm{LD}$ cows. For both groups, cell proliferation decreased during lactation. Analysis by terminal deoxynucleotidyl transferase dUTP nick end labeling revealed that the apoptotic index in mammary epithelial cells was less in SD cows than in LD cows. Expression of IGF-II mRNA increased during the dry period and into lactation and was greater in SD cows. Expression of IGF binding protein-5 mRNA increased during lactation, but was unaffected by day length. Expression of IGF-I did not differ over time or between treatments. We concluded that exposure to SD during the dry period enhanced mammary growth relative to $\mathrm{LD}$, and this may be related to increased expression of IGF-II. Treatment differences in the temporal pattern of proliferation indicated the existence of a critical period wherein photoperiod affects mammary gland development during the dry period.
\end{abstract}

(Key words: photoperiod, mammary growth, insulinlike growth factor-II, dry period)

Received January 3, 2005.

Accepted March 9, 2005.

Corresponding author: Thomas B. McFadden; e-mail: tmcfadde@ zoo.uvm.edu.
Abbreviation key: DABS-E = buffer containing 0.5 $M$ dibasic $\mathrm{NaPO}_{4}, 0.5 M$ monobasic $\mathrm{NaPO}_{4}, 2 \mathrm{M} \mathrm{NaCl}$, and $0.1 M$ EDTA, dpm = disintegrations per min, IGFBP-5 = IGF binding protein-5, LD = long day $(16$ h light:8 h dark) photoperiod, $\mathbf{P R L}=$ prolactin, PRL$\mathbf{R}=$ prolactin receptor, $\mathbf{S D}=$ short day $(8 \mathrm{~h}$ light: $16 \mathrm{~h}$ dark) photoperiod, $\mathbf{T d T}=$ terminal deoxynucleotidyl transferase, TUNEL = terminal deoxynucleotidyl transferase dUTP nick end labeling.

\section{INTRODUCTION}

The dry period is a critical part of the lactation cycle in dairy cows, and is essential for achieving optimal milk yield in the subsequent lactation (Capuco et al., 1997; Bachman and Schairer, 2003). This nonlactating period is required for remodeling processes in the gland, including regression (apoptosis), proliferation, and differentiation of mammary cells to prepare for the ensuing lactation (Turner and Huynh, 1991; Capuco et al., 1997; Bachman and Schairer, 2003). The importance of mammary remodeling in dairy cows has been demonstrated by experiments using split udder designs, which established that the need for a dry period is not nutritional, but is related to local changes in the mammary gland (Smith et al., 1966). In the absence of a dry period, yield in the subsequent lactation may be reduced by as much as 20\% (reviewed in Capuco and Akers, 1999; Bachman and Schairer, 2003).

In addition to reassessment of the optimal dry period length, novel strategies in dry cow management are being investigated to maximize milk yield during lactation. Any influence on mammary remodeling that increases mammary cell survival during the dry period may enhance milk yield during the subsequent lactation. One simple and noninvasive management tool that enhanced milk yield in the following lactation is manipulation of photoperiod during the dry period. Miller et al. (2000) reported that cows exposed to short day photoperiod (SD; $8 \mathrm{~h}$ light:16 h dark) during the entire 60 -d dry period subsequently produced $3.5 \mathrm{~kg}$ more milk per day than cows exposed to long day photoperiod (LD; 
$16 \mathrm{~h}$ light:8 h dark). A difference in milk yield between treatments was evident from the beginning of lactation. However, the mechanism whereby photoperiod increases milk yield is unknown. A better understanding of factors involved could lead to development of additional management strategies that utilize optimal timing and combinations with other interventions.

It is well established that relative to SD, exposure to LD leads to increased blood concentrations of prolactin (PRL; Newbold et al., 1991; Miller et al., 2000). In addition, increased serum PRL was associated with lower PRL receptor (PRL-R) expression in lymphocytes in calves (Auchtung et al., 2003), rats (Di Carlo et al., 1995), and in mammary tissue of calves (Auchtung et al., 2003), cows (Auchtung et al., 2005), and rats (Barash et al., 1983) as well as in liver and kidney of rats (Barash et al., 1983). Importance of PRL-R expression to mammary gland function was demonstrated in gene disruption studies in rodents (Ormandy et al., 2003). For example, PRL- $\mathrm{R}^{+/-}$mice fail to lactate because of impaired mammary development, indicating that successful mammary development during pregnancy is dependent on a threshold of PRL-R expression. Extrapolating these findings to ruminants, cows exposed to $\mathrm{LD}$, which have relatively increased serum PRL concentrations and reduced PRL-R expression, may experience a decrease in PRL signaling and impaired mammary development. Conversely, cows exposed to SD, which have relatively low PRL concentrations and high PRL$R$ expression, may experience enhanced effects of PRL during the dry period and enhanced mammary development. The importance of PRL in regulating mammary function in ruminants has been clearly established (Akers et al., 1981a,b). In addition, PRL enhances mammary growth in rodents by influencing components of the IGF axis (Tonner et al., 1997; Brisken et al., 2002; Hovey et al., 2003). In pregnant mice, PRL induces mammary gland expression of IGF-II mRNA, a known mammary mitogen, and survival factor (Brisken et al., 2002; Hovey et al., 2003). Prolactin also suppresses the expression of IGF binding protein-5 (IGFBP-5) mRNA in the mammary gland of pregnant rats (Tonner et al., 1997). This binding protein has been reported to sequester both IGF-I and IGF-II, thereby inducing apoptosis (Tonner et al., 1995). During involution, declining concentrations of blood PRL coincide with increased IGFBP-5 expression in mammary gland of rodents (Tonner et al., 1997) and cows (Accorsi et al., 2002). However, in rats supplemented with exogenous PRL at involution, the increase in IGFBP- 5 mRNA expression was absent and involution was delayed (Tonner et al., 1997). Moreover, Accorsi et al. (2002) demonstrated that PRL plays an important role in mammary cell survival in the bovine mammary gland by suppressing mammary expression of IGFBP- 5 mRNA.

Based on the role of PRL in regulating mammary growth in rodents as well as the relationship among photoperiod, PRL, and PRL-R in cattle, we hypothesized that exposure to SD during the dry period would enhance proliferation and survival of mammary cells in dairy cows. Furthermore, we hypothesized that these effects are mediated by the PRL-IGF signaling axis. Our objectives were to quantify proliferation and apoptosis in mammary tissue of cows exposed to either LD or SD during the dry period and to compare mammary expression of IGF-I, IGF-II, and IGFBP-5 mRNA in these cows.

\section{MATERIALS AND METHODS}

\section{Animals and Treatments}

Cows used in this study were a subset ( $\mathrm{n}=6$ per treatment) of animals from a larger study (Auchtung et al., 2005). Multiparous Holstein cows housed at the University of Illinois (Urbana) were dried off approximately $60 \mathrm{~d}$ before expected calving and assigned randomly to $\mathrm{LD}(\mathrm{n}=20)$ or $\mathrm{SD}(\mathrm{n}=19)$ during the projected 60-d dry period. During the dry period, cows were housed in a ventilated barn with controlled lighting. Lights were turned on at $0800 \mathrm{~h}$ and off at $1600 \mathrm{~h}$ for SD or at $2400 \mathrm{~h}$ for LD treatments. All cows were returned to natural photoperiod at parturition (April to June 2002). Cows received identical feeding management with feed and water available ad libitum. Additional details have been published in a companion paper (Auchtung et al., 2005). The University of Vermont and University of Illinois Institutional Animal Care and Use Committees approved all animal use.

\section{Mammary Biopsies}

Mammary biopsies were obtained $(\mathrm{n}=6$ cows per treatment) on $d-40,-20,-10$, and +10 relative to expected calving (dates relative to actual calving were $-46 \pm 2,-24 \pm 2,-9 \pm 2$, and $+11 \pm 2$ ). Mammary tissue was obtained from the rear quarters of each cow as described by Farr et al. (1996). Right rear quarters were biopsied at $-46 \mathrm{~d}$, left rear at $-24 \mathrm{~d}$, right rear at $-9 \mathrm{~d}$, and left rear at $+11 \mathrm{~d}$. Briefly, cows were sedated by intravenous injection of xylazine $\mathrm{HCl}(35 \mu \mathrm{g} / \mathrm{kg}$ of BW, Phoenix Pharmaceuticals, St. Joseph, MO). The region of the udder to be biopsied was clipped and scrubbed 3 times with an iodine scrub, and then rinsed with $70 \%$ ethanol. For local anesthesia, lidocaine $\mathrm{HCl}(3 \mathrm{~mL} ; 20$ $\mathrm{mg} / \mathrm{kg}$, Phoenix Pharmaceuticals) was administered in a line block above the biopsy site. An incision of approxi- 
mately $2 \mathrm{~cm}$ was made through the skin and gland capsule. A biopsy sample of approximately $500 \mathrm{mg} \mathrm{(} \mathrm{70}$ $\times 40 \mathrm{~mm}$ in diameter) was obtained, an absorbable hemostat (Surgicel, PSS, Wareham, MA) was inserted to enhance clotting, and the wound was closed with 18$\mathrm{mm}$ stainless steel woundclips (Autoclip, Clay Adams, Parsippany, NJ). Biopsy samples were trimmed of extraparenchymal tissue and a portion $(\sim 200 \mathrm{mg})$ was immediately frozen in liquid nitrogen for subsequent isolation of RNA. The remaining parenchyma was diced into explants that were used to measure incorporation of $\left[{ }^{3} \mathrm{H}\right]$-thymidine into DNA ( 100 mg), or were fixed in $10 \%$ buffered formalin for subsequent histological analysis $(\sim 5 \mathrm{mg})$.

\section{Mammary Proliferation Assay}

Mammary parenchyma was diced into explants and approximately $100 \mathrm{mg}$ was incubated in a shaking water bath for $1 \mathrm{~h}$ at $37^{\circ} \mathrm{C}$ in $3 \mathrm{~mL}$ of medium 199 (Sigma, St. Louis, MO) supplemented with $1 \mu \mathrm{Ci} / \mathrm{mL}$ of $\left[{ }^{3} \mathrm{H}\right]-$ thymidine (33 $\mathrm{Ci} / \mathrm{mmol}, \mathrm{ICN}$, Irvine, CA) to determine incorporation of $\left[{ }^{3} \mathrm{H}\right]$-thymidine into DNA. After incubation, explants were rinsed in PBS, (Sigma) and 5 to 6 explants were fixed in $10 \%$ buffered formalin overnight for histology. Remaining explants were blotted, weighed, and frozen in liquid nitrogen. Incorporation of $\left[{ }^{3} \mathrm{H}\right]$-thymidine into DNA was determined as described by Berry et al. (2001). Samples were homogenized at high speed for $45 \mathrm{~s}$ in $0.5 \mathrm{~mL}$ of DABS-E $(0.5$ $M$ dibasic $\mathrm{NaPO}_{4}, 0.5 M$ monobasic $\mathrm{NaPO}_{4}, 2 \mathrm{M} \mathrm{NaCl}$, and $0.1 M$ EDTA) buffer, $\mathrm{pH} 7.4$, and transferred to 12$\times 75$-mm polypropylene tubes. The homogenizer and tubes were washed 3 times with DABS-E $(0.5,1$, and $1 \mathrm{~mL}$ ) and the contents were added to the original homogenate, bringing the final volume to $3 \mathrm{~mL}$. Homogenates were centrifuged at $3000 \times g$ for $10 \mathrm{~min}$ at $4^{\circ} \mathrm{C}$ to pellet cellular debris. To precipitate DNA, $0.5 \mathrm{~mL}$ of ice cold $10 \%$ TCA and $10 \mu \mathrm{L}$ of $10 \%$ BSA were added to duplicate $100-\mu \mathrm{L}$ aliquots of supernatant. Samples were mixed and placed on ice for $10 \mathrm{~min}$. Samples were centrifuged at $5000 \times g$ for $10 \mathrm{~min}$, and the supernatant was aspirated and discarded. Ice-cold TCA $(250 \mu \mathrm{L})$ was added to wash the DNA pellet, and the sample was vortexed and centrifuged at $5000 \times g$ for $10 \mathrm{~min}$. The supernatant was discarded and $200 \mu \mathrm{L}$ of $0.3 M \mathrm{NaOH}$ was added to dissolve the DNA pellet. After dissolution, $20 \mu \mathrm{L}$ of $3 \mathrm{M} \mathrm{HCl}$ was added to neutralize the solution, and $200 \mu \mathrm{L}$ of the neutralized solution was added to $5 \mathrm{~mL}$ of aqueous scintillation cocktail (BioSafe2, Mt. Prospect, IL) in 7-mL scintillation vials. Vials were shaken and disintegrations per minute (dpm) were measured using a scintillation counter (6500 LS, Beck- man Instruments, Fullerton, CA). Samples were counted for $1 \mathrm{~min}$.

\section{DNA Assay}

Total DNA in tissue homogenates was measured as described by Labarca and Paigen (1980), but modified for assay in 96-well plates (Nunclon, Denmark). Duplicate $2-\mu \mathrm{L}$ aliquots of homogenate were pipetted into wells, and $98 \mu \mathrm{L}$ of DABS-E and $100 \mu \mathrm{L}$ of $2 \mu \mathrm{g} / \mathrm{mL}$ Hoechst 33528 dye (Sigma) were added. Duplicate blanks containing DABS-E and Hoechst dye were run in every assay. Samples were incubated for $20 \mathrm{~min}$. Fluorescence was determined using a fluorimeter spectrophotometer (KC4, Bio-Tek Instruments, Winooski, VT) with the excitation wavelength set at $360 \mathrm{~nm}$ and the emission wavelength at $460 \mathrm{~nm}$. The DNA content of homogenates was determined by comparison with a standard curve from serial dilutions of calf thymus DNA (Sigma). The assay was validated by demonstrating that a dilution series of mammary homogenate ran parallel to the standard curve. Fluorescence values obtained from the standard curve were used to generate a linear equation that was used to determine the DNA concentration of samples and to calculate the total amount of DNA in the original homogenate. Total amount of DNA in the original homogenate of each sample was divided by the wet tissue weight to determine micrograms of DNA per milligram of tissue. Disintegrations per minute obtained from the $\left[{ }^{3} \mathrm{H}\right]$-thymidine assay $(\mathrm{dpm} / \mathrm{mg}$ ) were divided by micrograms of DNA per milligram of tissue to determine disintegrations per minute per microgram of DNA.

\section{Autoradiography}

After incubation with $\left[{ }^{3} \mathrm{H}\right]$-thymidine, a portion of each mammary explant was fixed in $10 \%$ buffered formalin overnight and stored in $70 \%$ ethanol. Explants were then dehydrated through graded ethanol solutions $(70,95$, and $100 \%)$ and embedded in Immunobed (Polysciences Inc., Warrington, PA) following the manufacturer's instructions. Sections approximately $1.5 \mu \mathrm{m}$ thick were cut from each tissue block at intervals of at least $20 \mu \mathrm{m}$ to ensure that individual cells were not recounted. For autoradiography, NTB-2 track nuclear emulsion (Kodak, Rochester, NY) was heated to $45^{\circ} \mathrm{C}$ for $45 \mathrm{~min}$ in a water bath. Slides were dipped in emulsion in a darkroom, allowed to air dry, and then placed in a slide box. Boxes were wrapped in aluminum foil to prevent light exposure and then refrigerated (slides were exposed for $5 \mathrm{~d}$ at $4^{\circ} \mathrm{C}$ ). Slides were then removed from boxes, developed for $2 \mathrm{~min}$ in Dektol (Kodak), fixed for 4 min (Kodak Fixer), rinsed in running water for 
$15 \mathrm{~min}$, then allowed to air dry for $30 \mathrm{~min}$. Slides were stained with $0.5 \%$ azure II and $0.025 \%$ basic fuschin in a $0.5 \% \mathrm{Na}$-borate solution at $17^{\circ} \mathrm{C}$ for $10 \mathrm{~s}$ and coverslips were mounted with Cytoseal.

\section{Terminal Deoxynucleotidyl Transferase dUTP Nick End Labeling}

Detection of apoptotic cells in situ was performed utilizing terminal deoxynucleotidyl transferase dUTP nick end labeling (TUNEL). Fresh explants of biopsy tissue (not incubated in $\left[{ }^{3} \mathrm{H}\right]$-thymidine) were fixed in $10 \%$ buffered formalin overnight and stored in $70 \%$ ethanol. Samples were embedded in paraffin, sectioned at approximately $4 \mu \mathrm{m}$ thickness, and mounted onto silanized slides, with 2 sections mounted per slide. Embedding and sectioning was done by the histology lab at Fletcher Allen Hospital (Burlington, VT). A commercial TUNEL kit (ApopTag Plus Peroxidase, Chemicon International, Temecula, CA) was used in accordance with the manufacturer's protocol. Briefly, after deparaffinization and hydration, slides were incubated with proteinase $\mathrm{K}\left(60 \mu \mathrm{L}\right.$ per $\left.5 \mathrm{~cm}^{2}\right)$ for $15 \mathrm{~min}$ at room temperature $\left(17^{\circ} \mathrm{C}\right)$. Tissue sections were quenched in $3 \% \mathrm{H}_{2} \mathrm{O}_{2}$ in PBS $(2 \times 5 \mathrm{~min})$, incubated in equilibration buffer for 10 to $30 \mathrm{~s}$, and incubated with terminal deoxynucleotidyl transferase (TdT) for $1 \mathrm{~h}$ at $37^{\circ} \mathrm{C}$. For every 4 slides processed, one negative control was processed. For negative controls, the duplicate section on each slide was isolated with a PAP pen (Zymed Laboratories, San Francisco, CA) and was incubated in equilibration buffer instead of TdT. Sections were washed with stopwash buffer for $10 \mathrm{~min}$ at room temperature $\left(17^{\circ} \mathrm{C}\right)$ and then incubated with antidigoxigenin-peroxidase conjugate for $30 \mathrm{~min}$ at room temperature $\left(17^{\circ} \mathrm{C}\right)$. Sections were covered with plastic coverslips during the incubations with $\mathrm{TdT}$ and with antidigoxigenin-peroxidase to reduce edge and background staining. Tissue sections were washed in PBS $(4 \times 2 \mathrm{~min})$ and then incubated with diaminobenzidine for approximately $6 \mathrm{~min}$ at room temperature $\left(17^{\circ} \mathrm{C}\right)$ to develop color. Sections were washed in distilled $\mathrm{H}_{2} \mathrm{O}$, counterstained with $0.5 \%$ methyl green, washed 3 times in distilled water, dehydrated with butanol and xylene, and coverslips were mounted with Cytoseal.

\section{Quantification of Autoradiograms and TUNEL Slides}

Tissue sections were viewed by light microscopy with an Olympus BX41 light microscope (Olympus America Inc., Melville, NY) to quantify labeled cells. For each cow, 1 microscopic field was quantified. Fields were randomly selected and micrographs were taken at $40 \times$ magnification using Optronics Magnafire-SP (W. Nuhs- baum Inc., McHenry, IL). All cells in each field were counted (at least 1500 cells) using Image Pro Express (Media Cybernetics, L.P, Silver Spring, MD). For both autoradiograms and TUNEL preparations, cells were classified as epithelial, stromal, labeled epithelial, or labeled stromal cells. Cells were counted as epithelial if they were part of the secretory tissue, which included epithelial and myoepithelial cells, and possibly leukocytes if they were present in the alveolar lumen. All cells of the connective tissue were classified as stromal cells, including fibroblasts, adipocytes, and endothelial cells. For autoradiograms, cells were classified as labeled if they were overlaid with more than 10 silver grains per nucleus. For TUNEL, labeled brown nuclei were readily visible and a cell was classified as labeled when the nuclear staining was at least twice as intense as the background. Slides were coded for counting to prevent observer bias.

\section{RNA Isolation and Reverse Transcription}

Total RNA was isolated from each biopsy sample (approximately $200 \mathrm{mg}$ of tissue) using Trizol reagent (Invitrogen, Carlsbad, CA) according to the manufacturer's instructions. Total RNA was treated with deoxyribonuclease (DNA free, Ambion, Woodlands, TX) to remove contaminating DNA and with RNA Secure (Ambion) to inactivate ribonucleases. Integrity and quality of each total RNA sample was checked by measurement of optical density (260/280 nm; NanoDrop ND-1000, NanoDrop Technologies, Rockland, DE) and verified by inspection of $18 \mathrm{~S}$ and $28 \mathrm{~S}$ rRNA bands after agarose gel electrophoresis.

Total RNA ( $5 \mu \mathrm{g}$ ) was primed with $1 \mu \mathrm{L}$ of oligo dT primer $(0.5 \mu \mathrm{g} / \mu \mathrm{L}$, Invitrogen) and cDNA was synthesized using the SuperScript II reverse transcription kit (Invitrogen) according to the manufacturer's protocol.

\section{Real-Time Quantitative PCR}

Relative mRNA expression profiles were determined by real-time quantitative PCR using a PE 7700 thermal cycler (Applied Biosystems, Foster City, CA). Samples of cDNA from individual cows were diluted 1:4 in nuclease-free water, and $1 \mu \mathrm{L}$ was amplified in a 25 $\mu \mathrm{L}$ reaction mix containing $12.5 \mu \mathrm{L}$ of SYBR Green Jumpstart Taq Ready Mix (Sigma) and $0.25 \mu$ L internal reference dye (Sigma). Primers were designed for IGFI, IGF-II, and IGFBP-5 using Primer 3 software (http:// www-genome.wi.mit.edu/cgi-bin/primer/

primer3_www.cgi). For all transcripts, primers were designed from the complete coding sequence for each bovine transcript obtained from NCBI (http:// www.ncbi.nlm.gov). After primer design, the predicted 
Table 1. Primer sequences for bovine IGF-I, IGF-II, IGF binding protein-5 (IGFBP-5), and $\beta$-actin. ${ }^{1}$

\begin{tabular}{|c|c|c|c|}
\hline Target & GenBank no. & Primer & Sequence $5^{\prime}$ to $3^{\prime}$ \\
\hline \multirow[t]{2}{*}{ IGF-I } & $\mathrm{X} 15726$ & Forward & CTCCTCGCATCTCTTCTATCT \\
\hline & & Reverse & ACTCATCCACGATTCCTGTCT \\
\hline \multirow[t]{2}{*}{ IGF-II } & X53553 & Forward & ACCCTCCAGTTTGTCTGTGG \\
\hline & & Reverse & GGTGACTCTTGGCCTCTCTG \\
\hline \multirow[t]{2}{*}{ IGFBP-5 } & BF0762255 & Forward & TCCGAGATGGCAGAGGAG \\
\hline & & Reverse & GGTCACAGTTGGGCAGGT \\
\hline \multirow[t]{2}{*}{$\beta$-actin } & AY141970 & Forward & GCTCTCTTCCAGCCTTCCTT \\
\hline & & Reverse & GGACTCATCGTACTCCTGCTT \\
\hline
\end{tabular}

${ }^{1}$ Gene-specific primers for each target were designed using Primer 3 (http://www-genome.wi.mit.edu/ cgi-bin/primer/primer3_www.cgi) based on the available sequences in GenBank (accession numbers indicated). Amplicons were purified and sequenced, and product sequences were then BLAST-searched against the bovine genome to confirm the identity of the product.

product was BLAST-searched against the bovine database to ensure specificity of the primers. Gene-specific forward and reverse primers (Table 1$)$ were added $(0.1$ or $0.2 \mu M$ each), and nuclease-free water was added to bring the final concentration to $25 \mu \mathrm{L}$. The PCR reaction started with a $2-\min T a q$ activation step at $94^{\circ} \mathrm{C}$. Reactions were then subjected to 40 cycles of 15 -s denaturation at $94^{\circ} \mathrm{C}, 1$-min annealing at $60^{\circ} \mathrm{C}$, and 1 -min extension at $72^{\circ} \mathrm{C}$, followed by a final elongation step at $72^{\circ} \mathrm{C}$ for $5 \mathrm{~min}$. Optical data were collected at the end of each extension step, and relative expression of PCR products was determined by comparison with a standard curve. To generate the standard curve, equal amounts of undiluted cDNA of all individual cows were pooled and serial dilutions of the pool were run with the unknowns in each assay. Serial dilutions were: undiluted, 1:5, 1:10, 1:100, 1:1000, and a negative control (water). All samples and standards were run in duplicate and mean expression relative to the common pool was determined. After PCR, reaction products were melted and the temperature was reduced to allow for reannealing. Optical data were recorded during the temperature drop to ensure amplification of a single PCR product. In addition, PCR products were purified, sequenced, and BLAST-searched against the bovine genome to confirm the identity of the target. All gene expression values were normalized to that of $\beta$-actin in the same sample.

\section{Statistical Analyses}

Statistical analysis was performed using the Mixed Models procedure of SAS (Version 8.2, SAS Institute, Inc., Cary, NC). The model included treatment and time as fixed variables and cow as a random variable. Mammary biopsies (time) were included as repeated measures. Comparisons of means between treatments and days was performed using Fisher's protected LSD test, and significance was declared at $P<0.05$.

\section{RESULTS AND DISCUSSION}

Auchtung et al. (2005) reported milk yield, blood PRL concentrations, and PRL-R expression of all 39 cows in the study. Briefly, cows exposed to SD during the dry period produced approximately $3 \mathrm{~kg}$ more milk per day than $\mathrm{LD}$ cows during the first 16 wk of lactation. Concentrations of plasma PRL were less in cows exposed to SD, whereas expression of both forms of PRL-R was greater in mammary tissue and lymphocytes of these cows. Similar responses were observed in the subset of 12 cows reported on herein.

Mammary proliferation, measured by incorporation of $\left[{ }^{3} \mathrm{H}\right]$-thymidine into DNA, increased $(P<0.001)$ between -46 and $-9 \mathrm{~d}$, followed by a marked decrease $(P$ $<0.001$ ) between -9 and +11 d relative to parturition (Figure 1). These results agree with those from previous



Figure 1. Effect of days relative to calving and photoperiod on in vitro incorporation of $\left[{ }^{3} \mathrm{H}\right]$-thymidine into DNA by mammary tissue of cows. Mean incorporation of $\left[{ }^{3} \mathrm{H}\right]$-thymidine by mammary tissue of cows exposed to long day (open bars) or short day (filled bars) photoperiod during the dry period. Mammary biopsies were collected on $-46,-24,-9$, and +11 d relative to parturition. Each bar represents mean \pm SEM incorporation ( $\mathrm{dpm} / \mu \mathrm{g}$ of DNA) for cows in each photoperiod treatment at each biopsy ( 6 cows per treatment). Incorporation of $\left[{ }^{3} \mathrm{H}\right]$-thymidine into DNA was affected $(P<0.001)$ by time relative to calving and a treatment $\times$ time interaction $(P=0.09)$ was detected. 
work, which demonstrated that mammary tissue proliferation increased during the dry period (Capuco et al., 1997). In addition, we observed a treatment $\times$ time interaction, such that cows exposed to SD tended $(P=$ $0.09)$ to have an earlier increase in mammary proliferation during the dry period than LD cows (Figure 1). At $-46 \mathrm{~d}$ relative to parturition, incorporation of $\left[{ }^{3} \mathrm{H}\right]-$ thymidine did not differ between treatments (Figure 1). However, at $-24 \mathrm{~d}$ relative to parturition, incorporation of $\left[{ }^{3} \mathrm{H}\right]$-thymidine into DNA was 3 -fold greater $(P$ $<0.001$ ) in mammary tissue of cows exposed to SD compared with those on LD (Figure 1). Thereafter, proliferation of mammary tissue was similar for both groups. The treatment effect on mammary tissue proliferation on $\mathrm{d}-24$ indicated a specific time (3 to $6 \mathrm{wk}$ before parturition) in which SD photoperiod enhanced mammary cell proliferation. The mechanism by which SD exposure increases mammary tissue proliferation is not understood, however, it may involve treatment differences in the response to PRL signaling in the mammary gland. Exposure of these cows to SD resulted in greater expression of PRL-R mRNA compared with LD (Auchtung et al., 2005). The existence of a critical threshold in the abundance of PRL-R mRNA in mammary gland of pregnant mice has been demonstrated, and that threshold must be reached for normal mammary development and lactation to occur (Ormandy et al., 2003). A similar threshold of PRL-R expression in the mammary gland may also exist in ruminants. In addition, in explants of mammary tissue from lactating cows, PRL enhances mammary cell survival by impinging on the IGF axis (Accorsi et al., 2002). It is thus plausible that increased mammary tissue proliferation in cows exposed to SD is a result of increased PRL signaling due to greater PRL-R expression, which may influence the IGF axis and increase mitogenic activity in the mammary gland.

Autoradiography was used to determine proliferation indices for epithelial and stromal cells. Although patterns of proliferation observed in autoradiograms generally agreed with those of the thymidine assay, the effect of photoperiod did not differ (Figure 2). Treatment differences observed in the thymidine assay resulted not only from differences in epithelial cell proliferation, but also from stromal proliferation. Mammary epithelial cell proliferation increased $(P<0.01)$ during the dry period, then decreased $(P<0.01)$ during lactation (Figure 2A). The pattern of stromal cell proliferation was similar to that of the epithelium and was affected by time $(P<0.001$; Figure $2 \mathrm{~B})$. We observed a tendency $(P=0.1)$ for a treatment $\times$ time interaction, such that cows exposed to SD had an earlier increase in stromal cell proliferation during the dry period than LD cows (Figure 2B), in agreement with the results of the thymi-

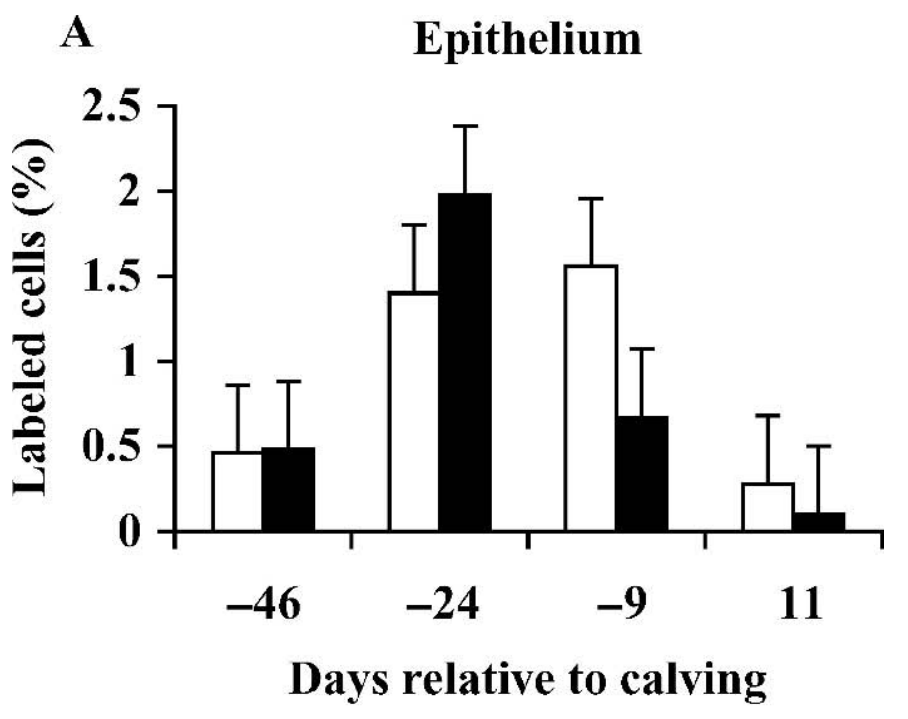

B

Stroma

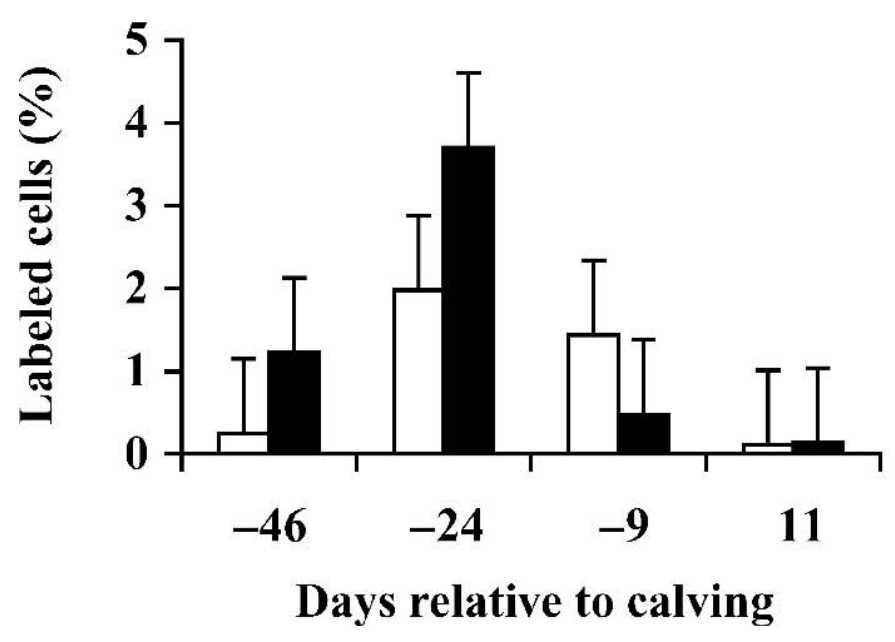

Figure 2. Effect of time and photoperiod on proliferation of epithelial (A) and stromal (B) cells in the mammary gland of cows. Mean labeling indices of proliferating cells of cows exposed to long day (open bars) or short day (filled bars) photoperiod during the dry period. Mammary biopsies were collected on $-46,-24,-9$, and $+11 \mathrm{~d}$ relative to parturition. Each bar represents mean \pm SEM percentage labeled cells for cows in each photoperiod group at each biopsy ( 6 cows per treatment). Percentage labeled epithelium was affected $(P<0.01)$ by time relative to calving, but was not affected by photoperiod treatment. Percentage labeled stroma was affected $(P<0.001)$ by time relative to calving. A tendency $(P<0.001)$ for a treatment $\times$ time interaction $(P=0.10)$ was detected.

dine assay. The large percentage of labeled stromal cells was noteworthy (Figure 2B). Because the majority of cells counted (both labeled and unlabeled) were epithelial, the significance of a large percentage of proliferating stromal cells may be misleading. More specifically, 
although the labeling index for stromal cells was greater than for epithelial cells (Figure 2), the actual number of labeled epithelial cells was twice that of stromal cells, as the tissue was composed mostly of epithelium.

Mammary epithelial cell apoptosis increased $(P<$ $0.05)$ slightly during the dry period then decreased $(P$ $<0.03)$ during lactation and tended $(P=0.10)$ to be greater overall in LD cows than in SD cows (Figure $3 \mathrm{~A})$. Stromal cell apoptosis was also affected $(P<0.001)$ by days relative to calving and temporal changes were more marked than those observed for epithelium (compare Figures 3A and 3B). Apoptosis in mammary stroma was not affected by photoperiod (Figure 3B). Percentage of apoptotic cells in the stroma of both groups during the dry period, however, was unexpectedly large (Figure 3B), suggesting that stromal remodeling may play an important role in this developmental stage. We further examined the distribution of dying cells between the stromal and epithelial compartments. Of all apoptotic cells counted, $29 \pm 4$ and $19 \pm 4 \%$ were epithelial in LD and SD cows, respectively (data not shown). These data indicate that the majority of apoptosis in both treatments occurred in stromal cells, but that in LD cows proportionally more programmed cell death occurred in the epithelium. Degradation and apoptosis of stromal cells during the dry period is a critical part of mammary remodeling in dairy cows. Our data indicate that both $\mathrm{LD}$ and SD cows underwent extensive stromal remodeling, based on the large percentage of stromal cells undergoing apoptosis, and the moderate percentage of stromal cells proliferating. Further, SD cows may have experienced more favorable mammary remodeling, as suggested by the increased level of mammary cell proliferation on $d-24$ relative to parturition.

Expression of IGF-II mRNA in the mammary gland increased $(P<0.001)$ during the dry period and remained elevated during lactation (Figure 4). In addition, overall expression of IGF-II mRNA was greater $(P=0.05)$ in SD than in LD cows (Figure 4$)$. Expression of IGF-II mRNA in mammary tissue of pregnant mice is induced by PRL stimulation (Brisken et al., 2002; Hovey et al., 2003). This is associated with an increase in the number of cells due to the mitogenic effects of IGF-II (Brisken et al., 2002). Those reports support the concept that in the present study, elevated IGF-II in $\mathrm{SD}$ cows is related to photoperiod effects on proliferation and apoptosis. The greatest treatment differences in expression of IGF-II mRNA were at $d-24$ and -9 relative to parturition. Growth differences, however, were mainly at $d-24$ relative to parturition. These results support our hypothesis that the critical time
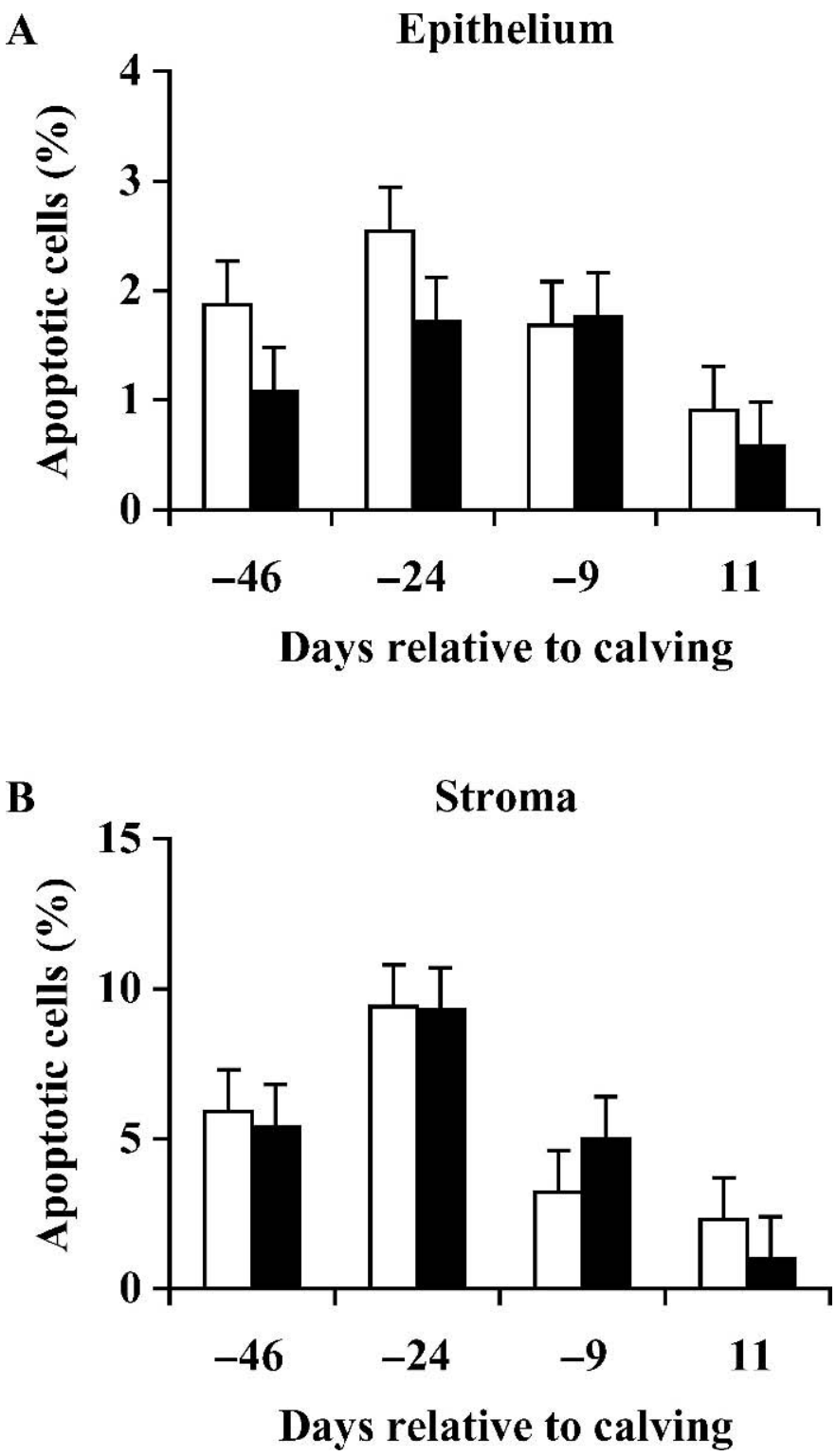

Figure 3. Effect of time and photoperiod on apoptosis of epithelial cells (A) and stromal (B) cells in the mammary gland of cows. Mean percentage apoptotic cells of cows exposed to long day (open bars) or short day (filled bars) photoperiod during the dry period. Mammary biopsies were collected on $-46,-24,-9$, and $+11 \mathrm{~d}$ relative to parturition. Each bar represents mean \pm SEM percentage labeled cells for cows in each photoperiod group at each biopsy ( 6 cows per treatment). Percentage apoptotic epithelium tended $(P=0.10)$ to be greater in LD cows and changed $(P<0.05)$ with days relative to calving. Percentage apoptotic stroma was not affected by photoperiod treatment, but was affected $(P<0.001)$ by days relative to calving.

when mammary growth can be increased by exposure to SD is between 3 and 6 wk before parturition.

Expression of IGFBP-5 mRNA increased $(P<0.001)$ from the dry period into lactation, but was unaffected by photoperiod treatment (Figure 5). The marked increase in IGFBP-5 mRNA expression during lactation 


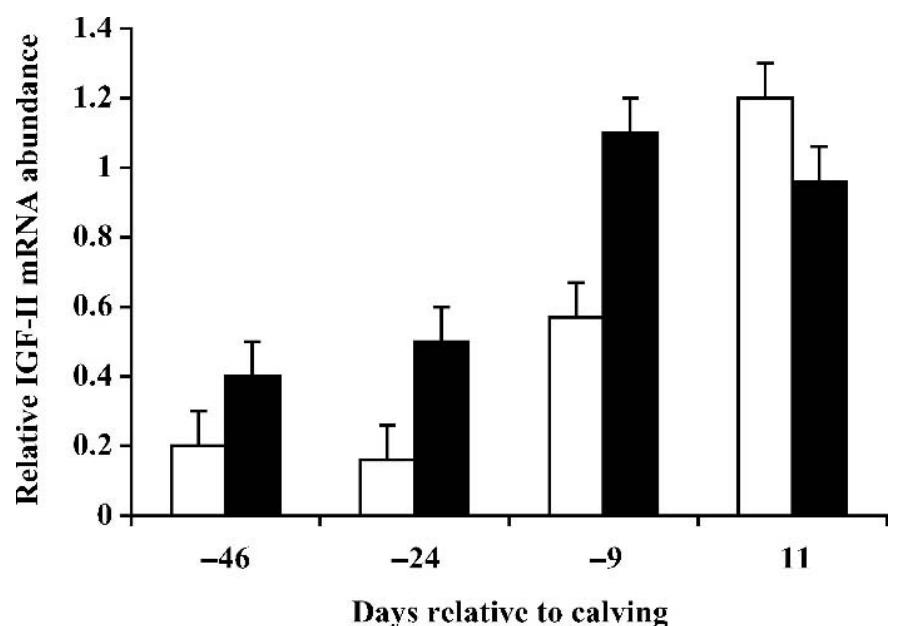

Figure 4. Effect of time and photoperiod on expression of IGF-II mRNA in the mammary gland of cows. Mean expression of IGF-II mRNA in mammary tissue of cows exposed to long day (open bars) or short day (filled bars) photoperiod during the dry period. Mammary biopsies were collected on $-46,-24,-9$, and $+11 \mathrm{~d}$ relative to parturition. The mRNA abundance was detected by real time quantitative reverse transcription-PCR. Each bar represents mean \pm SEM relative mRNA abundance normalized to $\beta$-actin for cows in each photoperiod treatment at each biopsy ( 6 cows per treatment). Expression of IGFII mRNA was affected $(P<0.001)$ by time relative to calving and was greater $(P \leq 0.05)$ in SD cows.

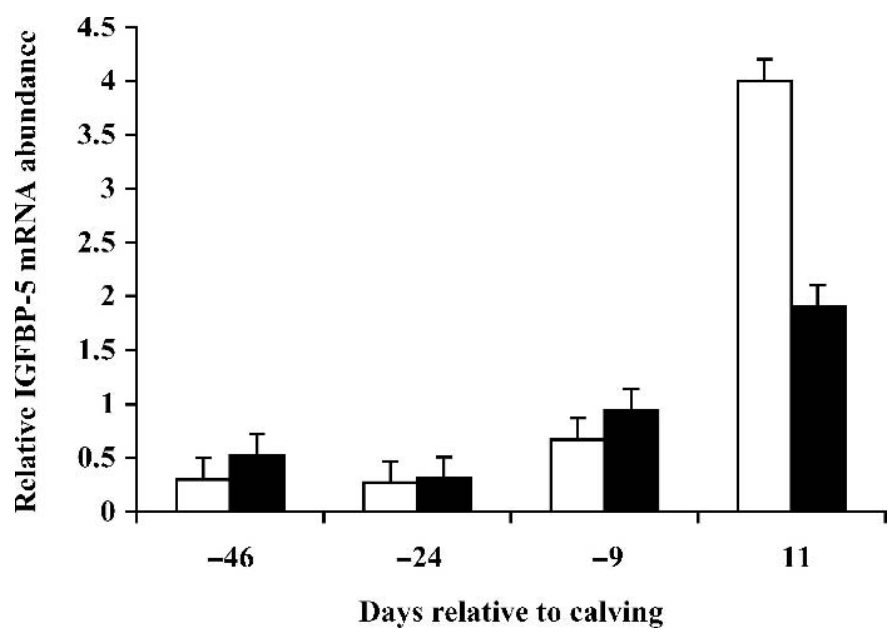

Figure 5. Effect of time and photoperiod on expression of IGF binding protein-5 (IGFBP-5) mRNA in mammary gland of cows. Mean expression of IGFBP-5 mRNA in mammary tissue of cows exposed to long day (open bars) or short day (filled bars) photoperiod during the dry period. Mammary biopsies were collected on $-46,-24,-9$, and $+11 \mathrm{~d}$ relative to parturition. Each bar represents mean \pm SEM relative mRNA abundance normalized to $\beta$-actin for cows in each photoperiod treatment at each biopsy ( 6 cows per treatment). Expression of IGFBP-5 mRNA was affected $(P<0.001)$ by time relative to calving, but not by photoperiod. A treatment $\times$ time interaction $(P<$ .01) was detected.

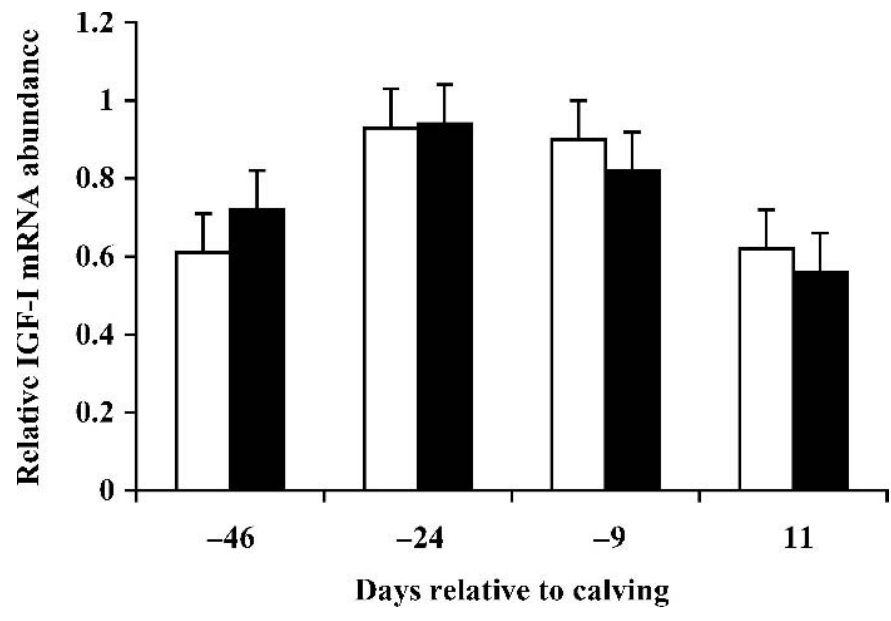

Figure 6. Effect of time and photoperiod on expression of IGF-I mRNA in mammary gland of cows. Mean expression of IGF-I mRNA in mammary tissue of cows exposed to long day (open bars) or short day (filled bars) photoperiod during the dry period. Mammary biopsies were taken on $-46,-24,-9$, and +11 d relative to parturition. Each bar represents mean \pm SEM relative mRNA abundance normalized to $\beta$-actin for cows in each photoperiod group at each biopsy ( 6 cows per treatment). Expression of IGF-I mRNA was not affected by time relative to calving or by photoperiod.

is surprising, as this binding protein is associated with initiation of mammary involution. In addition, expression of IGFBP-5 mRNA was reported to decrease from pregnancy into lactation in mice (Rudolph et al., 2003). However in rats (Rosato et al., 2002) and primiparous heifers (Plath-Gabler et al., 2001), expression of IGFBP5 mRNA increased from late gestation into lactation, in agreement with our observations. The species differences may reflect differences in physiological regulation of expression of IGFBP-5 mRNA, or in the functional role of IGFBP-5 during gestation and early lactation. Vega et al. (1991) found that IGFBP activity in mammary secretions in dairy cows (measured by binding of radiolabeled IGF-I and IGF-II) was greatest during the second half of the dry period and then decreased during late gestation and early lactation. Therefore, an increase in the expression of IGFBP- 5 mRNA in the mammary gland may not always translate to an increase in activity of the protein. Species differences may also exist in the binding activity of IGFBP-5 during various physiological states.

Expression of IGF-I mRNA in mammary tissue was not affected by time (Figure 6) or photoperiod treatment (Figure 6). It was reported that mammary gland expression of IGF-I mRNA decreased dramatically from late gestation to lactation in heifers (Plath-Gabler et al., 2001). Perhaps local IGF-I plays a more critical role in mammary gland development in heifers than in multiparous cows. Because concentrations of IGF-I in blood increase upon exposure of cows to LD during lactation, 
it has been suggested that IGF-I mediates the milk yield response to photoperiod during established lactation (Dahl et al., 1997). In the present study, we observed no effect of photoperiod treatment on mammary gland expression of IGF-I mRNA. Perhaps the increase observed in the latter study was a result of increased IGFI synthesis in the liver, rather than local synthesis in the mammary gland. In contrast to lactation, Miller et al. (2000) reported that the concentration of IGF-I in circulation during the dry period was unaffected by photoperiod and concluded that the effects of photoperiod during the dry period are not mediated through altered IGF-I. The conclusions of Miller at al. (2000) are in agreement with our findings, which suggest that local IGF-I is not involved in the mammary growth response observed in cows exposed to SD during the dry period.

Our results demonstrate that cows exposed to SD had greater mammary tissue proliferation at d -24 and less epithelial cell apoptosis during the dry period than LD cows. Increased mammary growth may be related to increased IGF-II mRNA expression in the mammary gland of SD cows. Based on our gene expression results, a role for local IGFBP-5 or IGF-I in mediating the effects of SD during the dry period is not supported.

\section{CONCLUSIONS}

We conclude that manipulation of photoperiod during the dry period elicits an effect on mammary growth between 3 and 6 wk before parturition. Our data indicate that cows exposed to SD undergo more extensive mammary remodeling and cell renewal, which may translate to increased milk production in the subsequent lactation.

\section{ACKNOWLEDGMENTS}

The authors thank Paul Kendall and Agustin Rius for assistance with animal handling. Thanks to Timothy Hunter and Mary Lou Shane for help with quantitative real-time PCR and data analysis, and to Alan Howard for statistical support. This research was funded by USDA-BARD (Award \#US-3201-01).

\section{REFERENCES}

Accorsi, P. A., B. Pacioni, C. Pezzi, M. Forni, D. J. Flint, and E. Seren. 2002. Role of prolactin, growth hormone and insulin-like growth factor 1 in mammary gland involution in the dairy cow. J. Dairy Sci. 85:507-513.

Akers, R. M., D. E. Bauman, A. V. Capuco, G. T. Goodman, and H. A. Tucker. 1981a. Prolactin regulation of milk secretion and biochemical differentiation of mammary epithelial cells in periparturient cows. Endocrinology 109:23-30.

Akers, R. M., D. E. Bauman, G. T. Goodman, A. V. Capuco, and H. A. Tucker. 1981b. Prolactin regulation of cytological differentia- tion of mammary epithelial cells in periparturient cows. Endocrinology 109:31-40.

Auchtung, T. L., P. E. Kendall, J. L. Salak-Johnson, T. B. McFadden, and G. E. Dahl. 2003. Photoperiod and bromocriptine treatment effects on expression of prolactin receptor mRNA in bovine liver, mammary gland and peripheral blood lymphocytes. J. Endocrinol. 179:347-356.

Auchtung, T. L., A. G. Rius, P. E. Kendall, T. B. McFadden, and G. E. Dahl. 2005. Effects of photoperiod during the dry period on prolactin, prolactin receptor, and milk production of dairy cows. J. Dairy Sci. 88:121-127.

Bachman, K. C., and M. L. Schairer. 2003. Invited Review: Bovine studies on optimal lengths of dry periods. J. Dairy Sci. 86:3027-3037.

Barash, I., Z. Madar, and A. Gertler. 1983. Down-regulation of prolactin receptors in the liver, mammary gland and kidney of female virgin rat, infused with ovine prolactin or human growth hormone. Biochem. Biophys. Res. Commun. 116:644-650.

Berry, S. D., T. B. McFadden, R. E. Pearson, and R. M. Akers. 2001. A local increase in the mammary IGF-1:IGFBP-3 ratio mediates the mammogenic effects of estrogen and growth hormone. Domest. Anim. Endocrinol. 21:39-53.

Brisken, C., A. Ayyannan, C. Nguyen, A. Heineman, F. Reinhardt, J. Tan, S. K. Dey, G. P. Dotto, R. A. Weinberg, and T. Jan. 2002. IGF-2 is a mediator of prolactin-induced morphogenesis in the breast. Dev. Cell 3:877-887.

Capuco, A. V., and R. M. Akers. 1999. Mammary involution in dairy animals. J. Mammary Gland Biol. Neoplasia 4:137-144.

Capuco, A. V., R. M. Akers, and J. J. Smith. 1997. Mammary growth in Holstein cows during the dry period: Quantification of nucleic acids and histology. J. Dairy Sci. 80:477-487.

Dahl, G. E., T. H. Elsasser, A. V. Capuco, R. A. Erdman, and R. R. Peters. 1997. Effects of a long daily photoperiod on milk yield and circulating concentrations of insulin-like growth factor-1. J. Dairy Sci. 80:2784-2789.

Di Carlo, R., C. Bole-Feysot, O. Gualillo, R. Meli, M. Nagano, and P. A. Kelly. 1995. Regulation of prolactin receptor mRNA expression in peripheral lymphocytes in rats in response to changes in serum concentrations of prolactin. Endocrinology 136:4713-4716.

Farr, V. C., K. Stelwagen, L. R. Cate, A. J. Molenaar, T. B. McFadden, and S. R. Davis. 1996. An improved method for the routine biopsy of bovine mammary tissue. J. Dairy Sci. 79:543-549.

Hovey, R. C., J. Harris, D. L. Hadsell, A. V. Lee, C. J. Ormandy, and B. K. Vonderhaar. 2003. Local insulin-like growth factor-II mediates prolactin-induced mammary gland development. Mol. Endocrinol. 17:460-471.

Labarca, C., and K. Paigen. 1980. A simple, rapid, and sensitive DNA assay procedure. Anal. Biochem. 102:344-352.

Miller, A. R., R. A. Erdman, L. W. Douglass, and G. E. Dahl. 2000. Effects of photoperiodic manipulation during the dry period of dairy cows. J. Dairy Sci. 83:962-967.

Newbold, J. A., L. T. Chapin, S. A. Zinn, and H. A. Tucker. 1991. Effects of photoperiod on mammary development and concentration of hormones in serum of pregnant dairy heifers. J. Dairy Sci. 74:100-108.

Ormandy, C. J., M. Naylor, J. Harris, F. Robertson, N. D. Horseman, G. J. Lindeman, J. Visvader, and P. A. Kelly. 2003. Investigation of the transcriptional changes underlying functional defects in the mammary glands of prolactin receptor knockout mice. Recent Prog. Horm. Res. 58:297-323.

Plath-Gabler, A., C. Gabler, F. Sinowatz, B. Berisha, and D. Schams. 2001. The expression of the IGF family and GH receptor in the bovine mammary gland. J. Endocrinol. 168:39-48.

Rosato, R., D. Lindenbergh-Kortleve, J. Neck, S. Drop, and G. Jahn. 2002. Effect of chronic thyroxine treatment on IGF-I, IGF-II and IGF-binding protein expression in mammary gland and liver during pregnancy and early lactation in rats. Eur. J. Endocrinol. 146:729-739.

Rudolph, M. C., J. L. McManaman, L. Hunter, T. Phang, and M. C. Neville. 2003. Functional development of the mammary gland: Use of expression profiling and trajectory clustering to reveal 
changes in gene expression during pregnancy, lactation, and involution. J. Mammary Gland Biol. Neoplasia 8:287-307.

Smith, A., J. V. Wheelock, and F. H. Dodd. 1966. Effect of milking throughout pregnancy on milk yield in the succeeding lactation. J. Dairy Sci. 49:895-896.

Tonner, E., M. C. Barber, M. T. Travers, A. Logan, and D. J. Flint. 1997. Hormonal control of insulin-like growth factor-binding protein-5 production in the involuting mammary gland of the rat. Endocrinology 138:5101-5107.

Tonner, E., L. Quarrie, M. Travers, M. Barber, A. Logan, C. Wilde, and D. Flint. 1995. Does an IGF-binding protein (IGFBP) present in involuting rat mammary gland regulate apoptosis? Prog. Growth Factor Res. 6:409-414.

Turner, J. D., and H. T. Huynh. 1991. Role of tissue remodeling in mammary epithelial cell proliferation and morphogenesis. J. Dairy Sci. 74:2801-2807.

Vega, J. R., C. A. Gibson, T. C. Skaar, D. L. Hadsell, and C. R. Baumrucker. 1991. Insulin-like growth factor (IGF)-I and -II and IGF binding proteins in serum and mammary secretions during the dry period and early lactation in dairy cows. J. Anim. Sci. 69:2538-2547. 